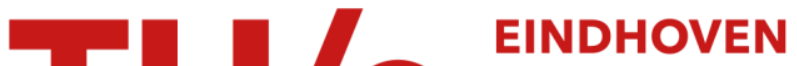 UNIVERSITY OF TECHNOLOGY
}

\section{The atomic hydrogen flux to silicon growth flux ratio during microcrystalline silicon solar cell deposition}

\section{Citation for published version (APA):}

Dingemans, G., van den Donker, M. N., Hrunski, D., Gordijn, A., Kessels, W. M. M., \& Sanden, van de, M. C. M. (2008). The atomic hydrogen flux to silicon growth flux ratio during microcrystalline silicon solar cell deposition. Applied Physics Letters, 93(11), 111914-1/3. [111914]. https://doi.org/10.1063/1.2987519

DOI:

$10.1063 / 1.2987519$

Document status and date:

Published: 01/01/2008

\section{Document Version:}

Publisher's PDF, also known as Version of Record (includes final page, issue and volume numbers)

\section{Please check the document version of this publication:}

- A submitted manuscript is the version of the article upon submission and before peer-review. There can be important differences between the submitted version and the official published version of record. People interested in the research are advised to contact the author for the final version of the publication, or visit the $\mathrm{DOI}$ to the publisher's website.

- The final author version and the galley proof are versions of the publication after peer review.

- The final published version features the final layout of the paper including the volume, issue and page numbers.

Link to publication

\section{General rights}

Copyright and moral rights for the publications made accessible in the public portal are retained by the authors and/or other copyright owners and it is a condition of accessing publications that users recognise and abide by the legal requirements associated with these rights.

- Users may download and print one copy of any publication from the public portal for the purpose of private study or research.

- You may not further distribute the material or use it for any profit-making activity or commercial gain

- You may freely distribute the URL identifying the publication in the public portal.

If the publication is distributed under the terms of Article 25fa of the Dutch Copyright Act, indicated by the "Taverne" license above, please follow below link for the End User Agreement:

www.tue.nl/taverne

Take down policy

If you believe that this document breaches copyright please contact us at:

openaccess@tue.nl

providing details and we will investigate your claim. 


\title{
The atomic hydrogen flux to silicon growth flux ratio during microcrystalline silicon solar cell deposition
}

\author{
G. Dingemans, ${ }^{1}$ M. N. van den Donker, ${ }^{1, a)}$ D. Hrunski, ${ }^{2}$ A. Gordijn, ${ }^{2}$ W. M. M. Kessels, ${ }^{3}$ \\ and M. C. M. van de Sanden ${ }^{3, b)}$ \\ ${ }_{1}^{1}$ IEF5-Photovoltaik, Forschungszentrum Jülich GmbH, D-52425 Jülich, Germany and Department \\ of Applied Physics, Eindhoven University of Technology, P. O. Box 513, 5600 MB Eindhoven, \\ The Netherlands \\ ${ }^{2}$ IEF5-Photovoltaik, Forschungszentrum Jülich GmbH, D-52425 Jülich, Germany \\ ${ }^{3}$ Department of Applied Physics, Eindhoven University of Technology, P. O. Box 513, 5600 MB Eindhoven, \\ The Netherlands
}

(Received 10 July 2008; accepted 17 August 2008; published online 19 September 2008)

\begin{abstract}
The $\mathrm{H}$ flux to $\mathrm{Si}$ growth flux ratio is experimentally determined under state-of-the-art silicon thin-film deposition conditions by employing the recently introduced etch product detection technique. Under the technologically relevant high-pressure depletion conditions and for different process parameter settings such as pressure, $\mathrm{SiH}_{4}$ concentration, rf power, and excitation frequency, it was demonstrated that the microcrystalline to amorphous silicon phase transition is uniquely and reactor independently determined by the flux ratio of $\mathrm{H}$ and $\mathrm{Si}$ growth species. (C) 2008 American Institute of Physics. [DOI: 10.1063/1.2987519]
\end{abstract}

The optimal phase composition of microcrystalline silicon $(\mu c-\mathrm{Si}: \mathrm{H})$ solar cell absorber layers is generally found in a narrow process window just before entering the amorphous growth regime. ${ }^{1-3}$ The presence of atomic hydrogen is recognized as a key parameter influencing the crystallinity of the silicon films. ${ }^{3-6}$ In the literature, it is often speculated that the hydrogen to $\mathrm{Si}$ growth precursor flux ratio should exceed a critical value for the nucleation of crystalline phase material to occur. Although the atomic hydrogen flux during deposition can in principle be determined by advanced techniques such as two-photon laser induced fluorescence or mass spectrometry, ${ }^{7,8}$ the technologically relevant data available concerning the abundance of atomic hydrogen during $\mu c$-Si:H deposition remain largely based on correlations with indirect optical emission spectroscopy measurements and modeling work. ${ }^{6,9-13}$

Preferential insertion of atomic hydrogen in strained $\mathrm{Si}-\mathrm{Si}$ bonds and subsequent silicon etching lead to a higher etch rate of amorphous silicon $(\mathrm{a}-\mathrm{Si}: \mathrm{H})$ relative to crystalline $\mathrm{Si}^{14-16}$ In a recent Letter, ${ }^{17}$ we demonstrated that this difference in etch rate can be exploited to determine in situ the phase composition of silicon films in the $\mu c-\mathrm{Si}: \mathrm{H}$ growth regime. In this letter we introduce a quantification of the etch product density in terms of the absolute atomic hydrogen flux. We will show that within the studied parameter range the $\mathrm{H}$ flux to $\mathrm{Si}$ growth flux ratio uniquely determines the phase transition of $\mu c-\mathrm{Si}: \mathrm{H}$ to a-Si:H (denoted by $\mu c-\mathrm{Si}$ $\rightarrow a-\mathrm{Si}$ ). These data experimentally confirm the existence of a critical $\mathrm{H}$ flux to $\mathrm{Si}$ growth flux ratio.

A parallel plate plasma reactor $(13.56 \mathrm{MHz}$, reactor A) with a substrate area of $10 \times 10 \mathrm{~cm}^{2}$ was used for most experiments. ${ }^{2,17,18}$ High pressure depletion process settings included a power range $\left(P_{\mathrm{rf}}\right)$ of $60-120 \mathrm{~W}$, a pressure $\left(p_{\text {dep }}\right)$ range of 5-15 Torr, a substrate temperature of $200{ }^{\circ} \mathrm{C}$, and a

\footnotetext{
${ }^{a)}$ Present address: Solland Solar BV, Bohr 10, 6422 RL Heerlen, The Netherlands.

b) Author to whom correspondence should be addressed. Electronic mail: m.c.m.v.d.sanden@tue.nl.
}

$\mathrm{H}_{2}$ flow $\left(f_{\mathrm{H} 2}\right)$ of 360 SCCM (SCCM denotes cubic centimeter per minute at STP). For each fixed setting of $p_{\text {dep }}$ and $P_{\text {rf }}$, the $\mathrm{SiH}_{4}$ flow $\left(f_{\mathrm{SiH} 4}\right)$ was varied between 0 and 10 SCCM to deposit films ranging from highly crystalline to purely amorphous silicon. Two other reactors were used for cross checking the experiments. In reactor B very-high-frequency excitation $(95 \mathrm{MHz}$ ) was employed and process settings included an electrode gap of 5-10 mm, $P_{\text {dep }}$ varying between 1.5 and 7.5 Torr, and showerhead or cross flow gas injection. Reactor $\mathrm{C}$ was a large area reactor with $30 \times 30 \mathrm{~cm}^{2}$ substrate area operated using deposition parameters similar to those for reactor A. ${ }^{19}$

An optical emission spectrometer allowed the collection of the plasma emission along the line of sight through a view port at the side of the reactors. Following the procedure described in Ref. 17, the phase composition of the as-deposited film $\left(\sim 150 \mathrm{~nm}\right.$ thick) was probed by detecting the $\mathrm{SiH}^{*}$ emission at $414.3 \mathrm{~nm}$ during a short $\mathrm{H}_{2}$ plasma step. Deposition rates $r_{d}$ were determined from thickness measurements by a step profiler. From $r_{d}$, the $\mathrm{Si}$ growth flux can be determined by multiplying it by the density of the deposited $\mathrm{Si}$ films $\left(\rho_{\mathrm{Si}} \sim 5 \times 10^{22} \mathrm{~cm}^{-3}\right)$. Complete $p-i-n$ solar cells were prepared by using $\mathrm{ZnO}$ coated glass substrates and 1 $\times 1 \mathrm{~cm}^{2}$ back contacts of evaporated Ag. Solar cell performance was measured under $1000 \mathrm{~W} / \mathrm{m}^{2}$ AM 1.5 illumination at a temperature of $25^{\circ} \mathrm{C}$.

To determine the $\mathrm{H}$ flux during the $\mathrm{H}_{2}$ plasma step, the baseline corrected $\mathrm{SiH}^{*}$ emission intensity $\left(I_{\mathrm{SiH}^{*}}\right.$, in arbitrary units) was converted to an equivalent flow of $\mathrm{SiH}_{4}$ etch products $\left(\Phi_{\mathrm{SiH} 4 \text {,etch }}\right)$ (in SCCM) in the procedure described below. Figure 1 shows $I_{\mathrm{SiH}^{*}}$ as a function of $f_{\mathrm{SiH} 4}$ for two process conditions in reactor $\mathrm{A}\left(P_{\mathrm{rf}}=80\right.$ and $\left.120 \mathrm{~W}\right)$. Note that the $\mathrm{SiH}^{*}$ emission at $f_{\mathrm{SiH} 4}=0$ is that part of the emission that can be attributed to the dissociation of etch products. The good linearity between $I_{\mathrm{SiH}^{*}}$ and $f_{\mathrm{SiH} 4}$ strongly suggests that the presence of small $\mathrm{SiH}_{4}$ fractions can be treated as an impurity in the $\mathrm{H}_{2}$ plasma. The amount of etch product generated and the result of exposing the $\mathrm{Si}$ thin films to a $\mathrm{H}$ flux, 


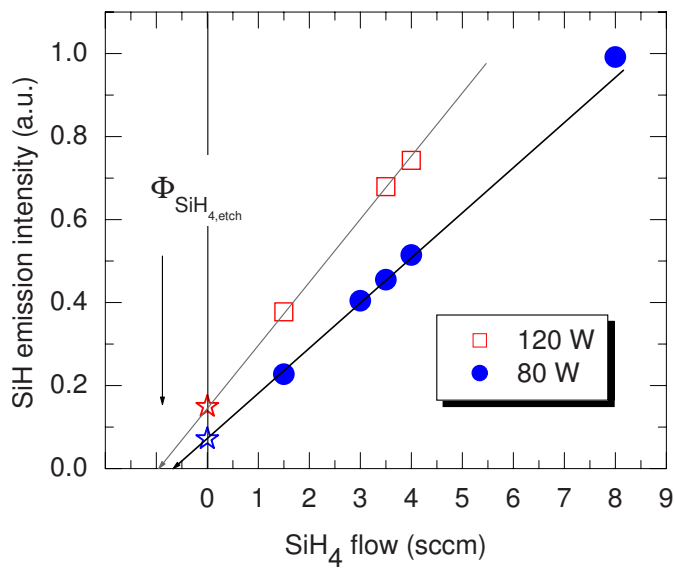

FIG. 1. (Color online) Baseline corrected $\mathrm{SiH}^{*}$ emission intensity at 414.3 $\mathrm{nm}\left(I_{\mathrm{SiH}^{*}}\right)$ as a function of $\mathrm{SiH}_{4}$ flow for 80 and $120 \mathrm{~W}$ rf power. Star symbols indicate $I_{\mathrm{SiH}^{*}}$ during $\mathrm{H}_{2}$ plasma probing. The $x$-interception (denoted $\Phi_{\mathrm{SiH} 4 \text {,etch }}$ ) is the equivalent etching induced $\mathrm{SiH}_{4}$ flow during $\mathrm{H}_{2}$ plasma probing.

expressed in an equivalent $\mathrm{SiH}_{4}$ flow $\Phi_{\mathrm{SiH} 4, \text { etch }}$, can be determined by extrapolating the linear fit to the $x$-intercept at $I_{\mathrm{SiH}^{*}}=0$. More information on the used linear dependence is given in Ref. 18. Note that this procedure should be repeated for every fixed plasma setting throughout a $f_{\mathrm{SiH} 4}$ optimization series. Furthermore, note that a sound determination of $\Phi_{\mathrm{SiH} 4, \text { etch }}$ relies on the correct subtraction of the baseline when determining $I_{\mathrm{SiH}^{*}}$. We cross checked the baseline subtraction by measuring $I_{\mathrm{SiH}}$ for $f_{\mathrm{SiH} 4}=0$ in a cleaned reactor with an uncoated substrate, in which indeed $I_{\mathrm{SiH}^{*}}=0$.

Figure 2 shows $\Phi_{\mathrm{SiH} 4 \text {,etch }}$ corresponding to films deposited with various $\mathrm{SiH}_{4}$ flows for the conditions $P_{\mathrm{rf}}=80 \mathrm{~W}$ and $P_{\mathrm{rf}}=120 \mathrm{~W}$ in reactor A. Three $\mathrm{SiH}_{4}$ flow regions can be identified in Fig. 2(a): an initial plateau region, a steep increase, and a second (sloping) plateau region. From solar cell analysis, as well as Raman spectroscopy, ${ }^{17}$ we deduced that

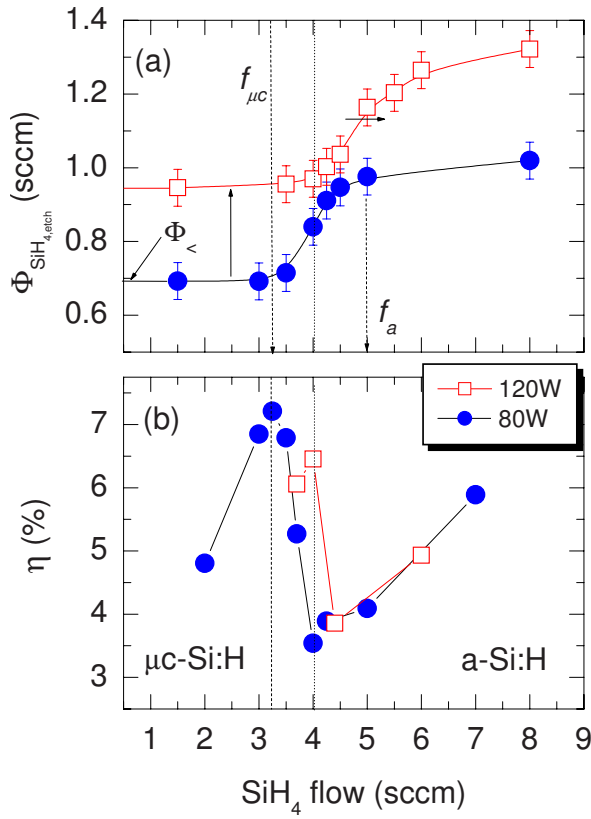

FIG. 2. (Color online) (a) $\mathrm{SiH}_{4}$ etch product flow during $\mathrm{H}_{2}$ plasma probing $\Phi_{\mathrm{SiH} 4, \text { etch }}$ as a function of the $\mathrm{SiH}_{4}$ flow during deposition $f_{\mathrm{SiH} 4}$ for $P_{\mathrm{rf}}=80$ and $120 \mathrm{~W}$. (b) Solar cell conversion efficiency $\eta$ for the two corresponding series of solar cells.
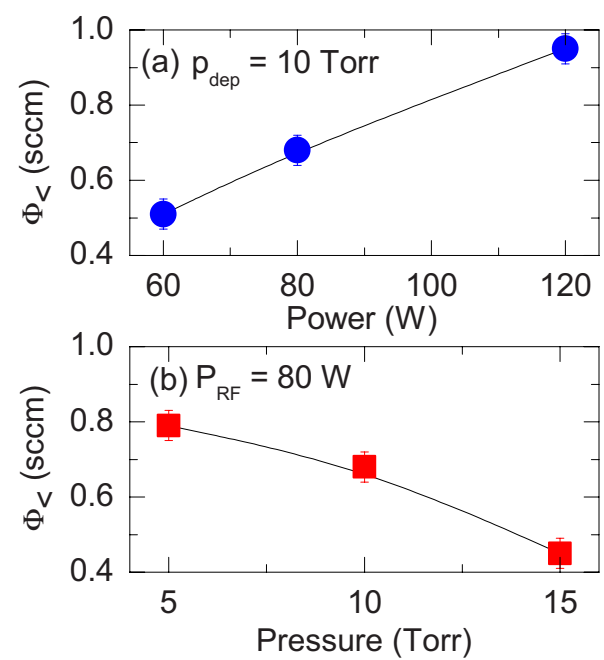

FIG. 3. (Color online) $\Phi_{<}$(etch product flow with $\mu c-\mathrm{Si}: \mathrm{H}$ film on substrate) for (a) different powers and (b) pressure conditions.

the transition from the first plateau region to the steep increase coincides with the onset of the phase transition to mixed phase growth (at $f_{\mathrm{SiH} 4}=f_{\mu c}$ ). ${ }^{17}$ We define the subsequent transition from the steep increase to the sloping plateau as the transition from mixed phase to amorphous silicon (at $f_{\mathrm{SiH} 4}=f_{a}$ ). In Fig. 2(b) we illustrate the correlation of etch product detection with the deposited material quality by showing the solar energy conversion efficiency $\eta$ of solar cells deposited for both the 80 and $120 \mathrm{~W}$ series. Highest efficiencies were obtained for films deposited at the onset of the phase transition, i.e., at $f_{\mathrm{SiH}_{4}}=3.2 \mathrm{SCCM}$ for $P_{\text {rf }}$ $=80 \mathrm{~W}$ and $f_{\mathrm{SiH} 4}=4.0 \mathrm{SCCM}$ for $P_{\mathrm{rf}}=120 \mathrm{~W}$.

Note that $\Phi_{<}$, defined as the etch product generation rate for etching of highly crystalline $\mu c-\mathrm{Si}: \mathrm{H}$ films in the plateau region of Fig. 2(a), is observed to increase from $0.7 \pm 0.05$ to $0.95 \pm 0.05 \mathrm{SCCM}$ when increasing $P_{\text {rf }}$ from 80 to $120 \mathrm{~W}$. As has been mentioned above, the linearity between $f_{\mathrm{SiH} 4}$ and $I_{\mathrm{SiH}}{ }^{*}$ (Fig. 1) and $f_{\mathrm{SiH} 4}$ and the deposition rate ${ }^{18}$ indicates that the influence of $f_{\mathrm{SiH} 4}$ on the $\mathrm{H}$ flux can be neglected in a first approximation (for small $\mathrm{SiH}_{4}$ concentrations, $0.2 \%$ $2 \%$ ), and we can state that the $\mathrm{H}$ flux during deposition is equivalent to the $\mathrm{H}$ flux during $\mathrm{H}_{2}$ plasma probing. We thus explain the higher $\Phi_{<}$for higher $P_{\mathrm{rf}}$ in terms of a larger atomic hydrogen flux toward the film surface under these conditions. To investigate the dependence of the $\mathrm{H}$ flux on process parameters, we consider $\Phi_{<}$in reactor A for various $P_{\text {rf }}$ and $P_{\text {dep. }}$. As can be seen in Figs. $3, \Phi_{<}$decreases with pressure and increases with power. These effects can be explained in terms of a lower electron temperature and smaller diffusion length for increasing pressure, and a rising electron density and dissociation rate of $\mathrm{H}_{2}$ as a result of the increase in power. ${ }^{20}$

The $\mathrm{H}$ flux toward the film surface $\Gamma_{\mathrm{H}}\left(\mathrm{cm}^{-2} \mathrm{~s}^{-1}\right)$, can now be expressed in terms of $\Phi_{<}$,

$$
\Gamma_{\mathrm{H}}=\left(\Phi_{<} / A_{\text {surface }}\right) / \gamma_{\text {etch }},
$$

with $\gamma_{\text {etch }}$ the etch yield of $\mathrm{H}$ atoms impinging on the film and $A_{\text {surface }}$ the total surface area exposed to the $\mathrm{H}$ flux (lower and upper electrode). $\Phi_{<}$is given in particles per second $\left(1 \mathrm{SCCM}=4.48 \times 10^{17}\right.$ particles s$\left.^{-1}\right)$.

To determine the absolute value of the $\mathrm{H}$ flux from Eq. (1), an appropriate value for the etch yield should be substi- 


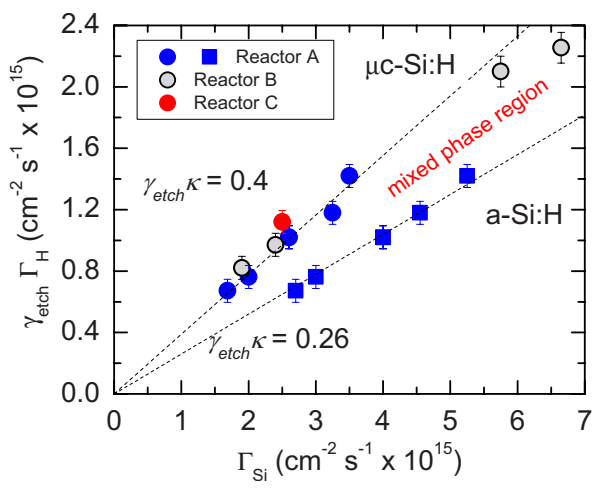

FIG. 4. (Color online) Phase diagram in the plane of the net silicon growth flux and a measure for the atomic hydrogen flux $\left(\gamma_{\mathrm{etch}} \Gamma_{\mathrm{H}}\right)$. Circles indicate $\mu c$-Si: $\mathrm{H}$ growth conditions at the onset of the phase transition (at flow $f_{\mu c}$ ), whereas squares represent $a-\mathrm{Si}: \mathrm{H}$ just after the complete transition (at flow $f_{a}$ ). Dotted lines along constant $\kappa \gamma_{\text {etch }}$ mark the transitions between the different phases.

tuted. Our results indicate that the etch yield is strongly dependent on the phase composition of the silicon film. In addition, factors such as substrate temperature, H-recombination probability, and ion bombardment should be taken into account for thorough analyses, as well as a possible difference in etch yield between the Si film on the upper electrode and on the lower electrode. For an order of magnitude estimate, however, an etch yield of $10^{-2}$ is assumed. $^{8,21}$ Therewith, from Fig. 3, H flux values between $6 \times 10^{16}$ and $2 \times 10^{17} \mathrm{~cm}^{-2} \mathrm{~s}^{-1}$ can be derived. Note that the order of magnitude of the $\mathrm{H}$ flux is in agreement with modeling results of high-pressure conditions of Lyka et al. ${ }^{13}$

To structure the discussion further, we introduce the dimensionless parameter $\kappa$, which is the ratio between the $\mathrm{H}$ flux $\Gamma_{\mathrm{H}}$ and the Si growth flux $\Gamma_{\mathrm{Si}}$,

$$
\kappa=\frac{\Gamma_{\mathrm{H}}}{\Gamma_{\mathrm{Si}}}=\frac{\left(\Phi_{<} / \mathrm{A}_{\text {surface }}\right) / \gamma_{\text {etch }}}{r_{d} \rho_{\mathrm{Si}}} .
$$

Next, we determined for the various power and pressure conditions of Fig. 3, the deposition rate for which the phase transition from $\mu c-\mathrm{Si}: \mathrm{H}$ to the mixed phase $(a+\mu c)$, and from $a+\mu c$ to $a-\mathrm{Si}: \mathrm{H}$ occurred. From Fig. 3, we know $\Phi_{<}$ for the corresponding deposition regimes and thus using Eq. (1), the appropriate $\gamma_{\mathrm{etch}} \Gamma_{\mathrm{H}}$. By plotting $\gamma_{\mathrm{etch}} \Gamma_{\mathrm{H}}$ versus $\Gamma_{\mathrm{Si}}$, we determined the slope $\kappa \gamma_{\text {etch }}$ for the transition data points in reactors A, B, and C. Figure 4 displays this main result of this letter and illustrates that the change in the phase composition of the material can be well described and understood in terms of only two parameters, namely, $\Gamma_{\mathrm{H}}$ and $\Gamma_{\mathrm{Si}}$. A qualitative view on the data behind Fig. 4 is that in a $f_{\mathrm{SiH} 4}$ optimization series (at constant $P_{\text {rf }}, p_{\text {dep }}$, excitation frequency or reactor geometry), the phase transition can be understood by variation in $\Gamma_{\mathrm{Si}}$ at constant $\Gamma_{\mathrm{H}}$. When changing any of the parameters $\left(P_{\mathrm{rf}}, p_{\mathrm{dep}}\right.$, excitation frequency, or reactor geometry), generally both $\Gamma_{\mathrm{H}}$ and $\Gamma_{\mathrm{Si}}$ change. However, the $\Gamma_{\mathrm{Si}}$ to $\Gamma_{\mathrm{H}}$ ratio $\kappa \gamma_{\text {etch }}$ at which the phase transition occurs, remains constant under the various reactor geometries and deposition conditions applied. This strongly suggests that the phase transition is uniquely determined by the $\mathrm{H}$ to $\mathrm{Si}$ growth flux ratio. These results might therefore indicate that under the used high-pressure high depletion deposition conditions the phase transition is a surface induced process, as $\kappa \gamma_{\text {etch }}$ re- flects a ratio between the time constant related to the arrival rate of atomic $\mathrm{H}$ and the time constant related to the growth rate of $1 \mathrm{ML}$ of silicon film.

Note that the absolute value for the $\mathrm{H}$ to $\mathrm{Si}$ growth flux ratio can be obtained by assuming again that $\gamma_{\text {etch }}$ is in the order of $10^{-2}$. We obtain $\kappa \approx 40$ for the $\mu c \rightarrow a+\mu c$ phase transition. Conversely reasoned, to comply with the modeled estimates of Strahm et al. ${ }^{11}(\kappa \approx 12)$ and Klein et al. ${ }^{3}(\kappa$ $\approx 5$ ), slightly higher values for $\gamma_{\text {etch }}$ between 0.03 and 0.05 seem more appropriate.

To summarize, the recently introduced technique of etch product detection was extended to determine the absolute $\mathrm{H}$ flux under $\mu c-\mathrm{Si}: \mathrm{H}$ deposition conditions. From the $\mathrm{H}$ flux the ratio between the $\mathrm{H}$ and $\mathrm{Si}$ growth flux was determined in the phase transition regime for three different reactors and various plasma settings. From the results, we infer that the $\mathrm{H}$ to Si growth flux ratio at which the phase transition occurs is a constant, which strongly suggests that the phase transition is governed kinetically by the arrival rate of atomic hydrogen relative to the arrival rate of the growth precursors. The insights obtained provide an outlook to achieve high growth rates for silicon thin films in or close to the mixed phase region.

We thank R. Schmitz, W. Appenzeller, M. Leotsakou, J. Wolff, and J. Kirchhoff for technical support.

${ }^{1}$ O. Vetterl, F. Finger, R. Carius, P. Hapke, L. Houben, O. Kluth, A. Lambertz, A. Mück, B. Rech, and H. Wagner, Sol. Energy Mater. Sol. Cells 62, 97 (2000)

${ }^{2}$ M. N. van den Donker, B. Rech, R. Schmitz, J. Klomfass, G. Dingemans, F. Finger, L. Houben, W. M. M. Kessels, and M. C. M. van de Sanden, J. Mater. Res. 22, 1767 (2007).

${ }^{3}$ S. Klein, F. Finger, R. Carius, and M. Stutzmann, J. Appl. Phys. 98, 024905 (2005).

${ }^{4}$ J. Kocka, T. Mates, H. Stuchlíková, J. Stuchlík, and A. Fejfar, Thin Solid Films 501, 107 (2006).

${ }^{5}$ P. Roca i Cabarrocas and S. Hamma, Thin Solid Films 337, 23 (1999).

${ }^{6}$ A. Matsuda, J. Non-Cryst. Solids 338-340, 1 (2004).

${ }^{7}$ X. R. Duan, H. Lange, and A. Meyer-Plath, Plasma Sources Sci. Technol. 12, 554 (2003).

${ }^{8}$ P. Kae-Nune, J. Perrin, J. Jolly, and J. Guillon, Surf. Sci. 360, L495 (1996).

${ }^{9}$ L. Guo, M. Kondo, M. Fukawa, K. Saitoh, and A. Matsuda, Jpn. J. Appl. Phys., Part 2 37, L1116 (1998).

${ }^{10}$ E. Amanatides, D. Mataras, D. Rapakoulias, M. N. van den Donker, and B. Rech, Sol. Energy Mater. Sol. Cells 87, 795 (2005).

${ }^{11}$ B. Strahm, A. A. Howling, L. Sansonnens, and Ch. Hollenstein, Plasma Sources Sci. Technol. 16, 80 (2007).

${ }^{12}$ J. K. Rath, R. H. J. Franken, A. Gordijn, R. E. I. Schropp, and W. J. Goedheer, J. Non-Cryst. Solids 338-340, 56 (2004).

${ }^{13}$ B. Lyka, E. Amanatides, and D. Mataras, J. Non-Cryst. Solids 352, 1049 (2006).

${ }^{14}$ M. Otobe, M. Kimura, and S. Oda, Jpn. J. Appl. Phys., Part 1 33, 4442 (1994).

${ }^{15}$ I. Solomon, B. Drévillon, H. Shirai, and N. Layadi, J. Non-Cryst. Solids 164-166, 989 (1993).

${ }^{16}$ M. Heintze, W. Westlake, and P. V. Santos, J. Non-Cryst. Solids 164-166, 985 (1993).

${ }^{17}$ G. Dingemans, M. N. van den Donker, A. Gordijn, W. M. M. Kessels, and M. C. M. van de Sanden, Appl. Phys. Lett. 91, 161902 (2007).

${ }^{18}$ M. N. van den Donker, B. Rech, W. M. M. Kessels, and M. C. M. van de Sanden, New J. Phys. 9, 280 (2007).

${ }^{19}$ T. Kilper, M. N. van den Donker, R. Carius, B. Rech, G. Bräuer, and T. Repmann, Thin Solid Films 516, 4633 (2008).

${ }^{20}$ E. Amanatides, S. Stamou, and D. E. Rapakoulias, J. Appl. Phys. 90, 5786 (2001).

${ }^{21}$ J. Abrefah and D. R. Olander, Surf. Sci. 209, 291 (1989). 